\title{
Training with Creating Spirit in Major Courses
}

\author{
Chunhui $\mathrm{Lu}^{1, \mathrm{a}}$ \\ ${ }^{1}$ School of Mechanical-Electronic Engineering, Hohai University, \\ Changzhou, China \\ achunhuill@yeah.net
}

\begin{abstract}
Creating spirit is an important quality and capability for engineering students who want to be good engineers. This spirit can make students try their best to study until they got Bachelor's Degree. At the same time, there are many conceptions which were taught in major courses to raise their capabilities in design production. The university training of Mechanical Engineering can help students to master the mechanical theory more easily by training. A new creation in teaching which gave all students a chance to design mechanical works after major courses and do presentations in class, which let them put more attention to study and competitions. This training style helped students to begin successful career as they finished training in past years in teaching process.
\end{abstract}

Keywords: Training, Creating Spirit, Major Course, Teaching Method, Mechanical

\section{Introduction}

It is well known that education decides a county's future. Many Chinese students of mechanical engineering were puzzled with how can use the theory they learned from classes. Now, after major courses, we trained students do more mechanical engineer works. This is a good chance to help students know the usage of theory. These students need combine the theory and practice together in training courses such as mechanical theory and mechanical design. They participate voluntarily in all sorts of items and competitions before get Bachelor's Degree.

The concept of 'theory and practice together' was put forward by Yangming Wang, a very famous philosopher of Ming dynasty in China. [1] A famous educator of UK who names John Henry said the initiation is not add a little knowledge but keep absorbing and combining large amount knowledge all we learned and we are learning, moves forward in our thought. [2]

In many years in Hohai University, a lot of exercises made students learn theory deeply and clearly, but they often know few facilities in productive progress. [3] The students shall design by teamwork and finish in two years, but they can turned to their lectures and tutors for advice and help. All the training items are thought by students, so the training content is abundant.
According to American education style, they debate questions in teams to finish their homework while few courses talked by English. In the end, students in a team are unity and fraternity as good friends. [4] When the students graduated from the universities, they can adapt to circumstance easier. [5] The only shortcoming in the training is few students in teamwork would wait for others or afford easy work. But in the end, many professors gave lower scores to them. Even if there are these lazy people, all students in training team got brilliant future in their career.

\section{Creating Spirit Training}

Creating capability is the most difficult capability to training. But when people talked about university students, they often admitted that American students are better than other countries'. How the situation appeared in last decades? As an exchange scholar to visit USA, I found the teaching style is a focus in research. In American universities education, they emphasis that universities are set for peoples to improve their knowledge level, not for the degree. [2] Many universities aboard ask students finish a few projects by teamwork. Compare to Chinese mechanical engineer education, the training method overseas has its advantages. [3].

So we can see the difference in two countries' universities. The creating capability was gotten by training in teaching process. If the students aware that they can get many medals or cups by training, they will active in creating groups. The task is let students analyze examples in major courses themselves and use the principles in project. If students have chance to produce a work which design by them, they should find shortcomings to let the object perfect. If the works included creating elements and are improved by professors, they may admit by patent office or put the wisdom on papers. Thus the students can be on the top in students and get many credits after class. At the beginning of creating training, students shall be trained in two steps. The first one is given good presentations.

\subsection{Presentation Set}

Students are not familiar to invention new things when they just study courses. But the major course lecturer teaches them major knowledge. In their four and five semesters, the 
students began hold how to use mechanical principles in design. For training the students' capability and confidence, the lecturer let students do presentations in projects. Mechanical Engineering Introduction is one major course and it shall introduce machine types, production process, and automation or auto-control conceptions in classes. In every three weeks, the students should give presentations in class time to show what they know from the chapters and what they want to do next. For forbidding some students read references collected by others, the reporter must face to questions form teacher and classmates. The teacher shall give scores to people who ask or answer questions according to their expression. Sometimes the reporter answered weakening because the questions are so tough. Though the presentations took some time in the class, students had gotten experience by this training and gave free rein to their imagination. After they fully discussed their designs, students can be easy to get the conclusion and decide the finally plan by themselves. The teacher would not take part in students' debate. He gave advice in the end of presentation to revise the plan.

\subsection{Works Competition and Exhibiting.}

The second step in training term is to finish a work in time to take part in competition or exhibiting. The lecturers reformed old methods which was remember principles and exercises but to encourage students to take part in all sorts of competitions.

In past ten years, many homecoming days gave us feedback information about shortcomings in old training style. When more and more students began to work after graduation, they find out that experience is very important in working. But how can a student get experience in university? Most Chinese students touch few examples in their study time in university. The more people did, the more they realized laws in work. So the Chinese students can grasp this key after they do more exercises.

We can conclude an experience from American students. Why they can do research in their high school? Because the America teachers encouraged people devote them into science research. In the teacher's mind, experience is not whole; students' creating capability is the most important advantage.

In Mechanical Engineering Introduction course, teacher introduced machinery, and introduced many works finished by senior students. By the way, the students should hear of which one got a high score in some competition and which one made an invention in his spare time. Students were encouraged to take part in a competition or an interesting team to train the creation thought. They can recognize how important the readymade experience in the progress is. Many competitions asked students use software to show the design structure, control the machine move and curve some parts with machine in competition site by themselves. So the university professors guide students design. When they won the competition, most students in training knew software well in training term such as AutoCAD, UG,
Solidworks and Pro-Engineer, etc. The high level competitions always need students demonstrate their works by software and videos.

\section{Major Courses Training in Mechanical Engineering}

\subsection{Thinking independently and newly}

Mechanical engineering is a very difficult project to many people especially in doing some works new. Every student got good scores with independent spirit as well as made great progress in working capability. At first, the professors asked students design a new thing to supply one or few functions. If the works are prepared for one competition, the professors will give the topic to students and let one person think out two plans to give advice. Students shall never forget the shortcomings in detail which was point out. If one team included five students, they should supply ten plans. This can inspire others; especially the major professors find the creating thinking in them. Second step is to combine the plans into one design. The professors let students debated several times to choose the best one, while give them presentation time to exhibit everyone's train of thought. The third step is product the design into a real object.

\section{2 'Theory and Practice Together' in Production Process}

Some designs are very practical which combined with problems and wait for students to solve. Some topic is let students settle a question in people's life. The production is not very easy to finish. Sometimes the workers give troubles to students or they cannot up to our requirement. Students shall go out to buy or find a proper factory to get good parts. In the production process, every student will afford one or two process and the result often out of control. When there are some problems in production, professors will not help them at once but let they try to solve problems in one week. If the students cannot find the reason of trouble, teachers will supply a few plans to settle it. This help students grow up than others and increase the students' abilities.

When students take part in competition, they must write a report and give a picture recorder to committee to check the production before the competition. In general, the production used courses knowledge so that they can pass the examination easily. Engineering students got knowledge not just need remember the exercise answer but made theory and practice together. The students practiced to choose different methods and paths to solve problems through designs.

In fact, college students need not design a complicated thing but need design something new by themselves. Each time the design plans we gave to competition committee are not same as before. This keeps practice students designed new things not old ones like other teams', which perhaps were not adapt to the competition topic. 


\section{Conclusion}

Creating training is a new education style in university teaching. Independent thought and useful training can help students to grasp main points in knowledge, and make students cooperation. Mechanical engineering students can learn theory and practice together. The training got big success in five years. Thus the students can become good engineers in short time. Over thirty students got patents, won in all sorts of competitions. Finally, they were accepted by first level universities or companies in China. This training process gave students training and projects more, taught independence sprit in studying, asked students combine theory and practice. The students who trained two to three years all got some awards and had confidence when they left the university.

\section{References}

[1] Chunhui Lu, Differences in University Engineering Education between China and USA, PMSS2013, (Advanced Education Research Vol 16) P249-252, 2013

[2] Chunhui Lu, 'Theory and Practice Together' in American Engineering Education, (Trans Tech Publications Ltd, ICAM2011, Part 1) P538-541

[3] Chunhui Lu, Training with 'Theory and Practice Together' in 'Excellent Engineer Plan' , MIM 2014, now in press

[4] Qirong Wang Edited, Lectures in Oxford---the Energy of Spirit, (Publishing House of Civil Aviation) Page 67, 2002 (In Chinese)

[5] Yubo Yin, Jianping Cai, Research in Chinese and American Courses of CAD System, Mechanical Courses Conference Research Papers, (Publishing House of College Education) P 43-47, 2010 (In Chinese) 